\title{
A comparative study of intra-cervical foley's catheter and PGE2 gel for induction of labour at term
}

\author{
Anjali R. Kanada*, Mahima Jain
}

Department of Obstetrics and Gynecology, B. J. Medical College, Civil Hospital, Ahmedabad, Gujarat, India

Received: 26 June 2019

Accepted: 05 August 2019

\section{*Correspondence:}

Dr. Anjali R. Kanada,

E-mail: anjalikanada@gmail.com

Copyright: (c) the author(s), publisher and licensee Medip Academy. This is an open-access article distributed under the terms of the Creative Commons Attribution Non-Commercial License, which permits unrestricted non-commercial use, distribution, and reproduction in any medium, provided the original work is properly cited.

\begin{abstract}
Background: In cervical ripening, before induction of labour, is needed to increase the success of labour induction, to reduce complications and to diminish the rate of caesarean section and duration of labour. Pharmacological preparations are in widespread use for cervical ripening but are not free from side-effects and complications. Mechanical methods, i.e. the use of Foley's catheter balloon, though effective have not gained much popularity because of the fear of infection. Therefore, the study has been conducted to prove the efficacy and safety of extra amniotic Foley catheter balloon and to compare it with intra-cervical prostaglandin E2 (PGE2) gel. The objective of the study was to the success of induction of labor depends on the cervical status at the time of induction. For effective cervical ripening both Foley's catheter and PGE2 gel are used. The aim of this study was to compare the efficacy of intra cervical Foley's catheter and intra cervical PGE2 gel in cervical ripening for the successful induction of labor.

Methods: A randomized, comparative study was conducted in the department of obstetrics and gynaecology, Civil hospital, B.J. Medical College Ahmedabad, during a period of 8 month from September 2018 to April 2019. 100 patients at term with a Bishop's score $\leq 5$ with various indications for induction were randomly allocated to group $\mathrm{F}$ (intra-cervical Foley's catheter) and group P (PGE2 gel) with 50 women included in each group.

Results: The groups were comparable with respect to maternal age, gestation age, indication of induction and initial Bishop's score. Both the groups showed significant change in the Bishop's score, 5.10 \pm 1.55 and 5.14 \pm 1.60 for Foley's catheter and PGE2 gel, respectively, $\mathrm{p}<0.001$. However there was no significant difference between the two groups. There was no significant difference in the side effects and caesarean section rate in both groups. The induction to delivery interval was $16.01 \pm 5.50$ hours in group $\mathrm{F}$ and $16.85 \pm 3.81$ hours in group $\mathrm{P}(\mathrm{p}=0.073)$. Apgar scores, birth weights and NICU admissions showed no significant difference between the two groups.

Conclusions: The study shows that both Foley's catheter and PGE2 gel are equally effective in pre induction cervical ripening.
\end{abstract}

Keywords: Cervical ripening, Foley's catheter, Induction of labor, PGE2

\section{INTRODUCTION}

Induction of labor is a common procedure in obstetrics. It is usually performed when risk of continuing a pregnancy is more than benefit of delivery. Cervical ripening has got a close relationship with the success rate of delivery. ${ }^{1}$ Cervical ripening refers to a process of preparing the cervix for induction of labor by promoting effacement and dilatation as measured by Bishop's score. ${ }^{2}$ Induction of labour should be safe, simple and effective. The success of induction depends upon the consistency, compliance and configuration of cervix. With low Bishops score, there may be increased rate of caesarean section delivery, maternal fever and fetal hypoxia. ${ }^{3,4}$ 
There for a simple and effective method for pre induction cervical ripening is of use. Ripening of cervix may be achieved by mechanical techniques such as introduction of trans-cervical Foleys catheter. Embrey and Mollison first described the use of a trans- cervical Foley's catheter for the cervical ripening. Currently Foley's catheter balloon is the most commonly used mechanical device for labour inducton ${ }^{5,6}$

It can cause mechanical dilatation of cervix and stimulates endogenous release of prostaglandins by stripping the fetal membranes and release of lysosomes from decidual cells. Use of catheter is associated with reduced induction delivery interval, decrease caesarean section rate, increase rate of spontaneous vaginal delivery. Chances of infection are no more than that of the usual hospital rate if strict aseptic precautions are observed $^{7}$

Intra-cervical application of PGE2 gel is also found to be effective for ripening of cervix as it can have a combined contraction inducing and cervical ripening effect. ${ }^{8}$ It is in use since 1960 s for cervical ripening.

Local application of PGE2 causes direct softening of cervix by a number of different mechanisms. It can cause connective tissue softening, cervical effacement and uterine activity. PGE2 gel can be used in cases of heart disease, PIH and eclampsia also., ${ }^{9,10}$

The purpose of the study was to compare the efficacy of intra-cervical Foley's catheter with PGE2 gel for preinduction cervical ripening. The induction delivery interval, maternal and fetal outcomes and the need for augmentation of labor in these two groups were also compared.

\section{METHODS}

A randomized, comparative study was conducted in the Department of Obstetrics and Gynaecology, Civil Hospital, B.J. Medical College, Ahmedabad, for a period of 8 month from September 2018 to April 2019. 100 patients at term with a Bishop's score $\leq 5$ with various indications for induction were randomly allocated to group F (intra-cervical Foley's catheter) and group $\mathrm{P}$ (PGE2 gel) with 50 women included in each group.

All the cases fulfilling the inclusion and exclusion criteria and willingness to participate in the study were included in the study and they were divided into two groups.

\section{Inclusion criteria}

- $\quad$ Primigravida

- $\quad \geq 37$ weeks of gestation

- Singleton pregnancy

- Cephalic presentation

- Bishop's score $\leq 5$

- Intact membranes.

\section{Exclusion criteria}

- Multiple pregnancy

- Malpresentation

- Absent membrane

- Antepartum haemorrhage

- Previous uterine scar

- Medical diseases, e.g. heart disease, renal disease, etc.

- Cephalopelvic disproportion.

The patients were randomly allocated to either Foley's catheter (group F) or PGE2 gel (group P) method. The Bishop's score was determined earlier. Each patient was questioned in detail and examined thoroughly. Last menstrual period was ascertained and correlated clinically.

\section{Primary outcome}

- Post induction Bishop's score was assessed after 6 hours of induction preferably by the same person.

\section{Secondary outcome}

- Demographic profile, gestation age, improvement of Bishop's score, induction-delivery interval, mode of delivery and feto-maternal outcome were noted

- Dose repetition of PGE2 gel was considered if post induction Bishop's score become $\leq 6$ in both the groups.

- Need of augmentation of labor was assessed and implemented by other methods such as artificial rupture of membrane (ARM) and/or oxytocin administration

- Failure of induction was declared if patient failed to go in active phase of labor within 48 hours of induction.

\section{Foley's catheter}

An 18 size Foley's catheter (it comes in pre-sterilized pack using ethylene oxide) was introduced through cervix to extra-amniotic space using a sterile technique with the aid of a speculum and sponge holding forceps and $30 \mathrm{ml}$ distilled water was instilled into the balloon. Then balloon is pulled up to the internal os. Catheter was tapped with thigh. Prophylactic antibiotic was given. The catheter was left undisturbed until spontaneous expulsion or no longer than 12 hours.

\section{Prostaglandin gel}

PGE2 gel is available in the name of cerviprime gel as a sterile preparation containing $0.5 \mathrm{mg}$ of dinoprostone per $3 \mathrm{gm}(2.5 \mathrm{ml})$ of gel in a prefilled syringe with a catheter for endocervical application. After exposing the cervix by speculum $0.5 \mathrm{mg}$ of PGE2 was inserted intra-cervically from a loaded syringe and the patients were kept in lying down position at least 30 minutes for absorption of drugs. 


\section{Statistical methods}

Student's $\mathrm{t}$ test and Chi square test was used to statistically compare the two groups. Differences with a $p$ value of $<0.05$ was considered statistically significant with the confidence interval of $95 \%$.

\section{RESULTS}

Group F and Group P had 50 randomized patients each. Both the groups were comparable with respect to the maternal age, gestational age, indication for induction and pre-induction Bishop's score.

No statistically significant difference was demonstrated between the two groups. Majority of the patient were between the age of $21-25$ years. The mean age of patient was $22.59 \pm 3.38$ years and $22.32 \pm 3$ years respectively in group1 and group2 (Table 1). The mean gestational age was $38.48 \pm 1.35$ weeks in group 1 and $38.43 \pm 1.29$ weeks in group 2 (Table 2). The most common indication for induction of labor in the present study was pregnancy induced hypertention.
In the present study, there was a significant increase in post -induction Bishop's score in both the study groups. However no significant difference in the mean changes in the two groups could be established.

Table 1: Demoraphic profile.

\begin{tabular}{|c|c|c|c|}
\hline Variables & Group F & Group P & p value \\
\hline $\begin{array}{l}\text { Maternal age } \\
\text { (years) }\end{array}$ & $22.59 \pm 3.38$ & $22.32 \pm 3$ & $\begin{array}{l}0.55 \\
(p>0.05)\end{array}$ \\
\hline $\begin{array}{l}\text { Gestational } \\
\text { age (weeks) }\end{array}$ & $38.48 \pm 1.35$ & $38.43 \pm 1.29$ & $\begin{array}{l}0.78 \\
(p>0.05)\end{array}$ \\
\hline $\begin{array}{l}\text { Indication for } \\
\text { induction }\end{array}$ & $\mathbf{n}=\mathbf{5 0}$ & $\mathrm{n}=\mathbf{5 0}$ & \\
\hline $\mathrm{PIH}$ & $20(40 \%)$ & $18(36 \%)$ & \\
\hline Postdatism & $16(32 \%)$ & $14(28 \%)$ & \\
\hline IUGR & $3(6 \%)$ & $4(8 \%)$ & \\
\hline $\begin{array}{l}\text { Oligo- } \\
\text { hydramnios }\end{array}$ & $1(2 \%)$ & $2(4 \%)$ & \\
\hline IUFD & $3(6 \%)$ & $4(8 \%)$ & \\
\hline Others & $7(14 \%)$ & $8(16 \%)$ & \\
\hline
\end{tabular}

$(\mathrm{p}<0.05$ was statisticaly significant $)$

Table 2: Change in Bishop Score.

\begin{tabular}{|llll|} 
Bishop's score & Group-F (Mean \pm SD) & Group-P(Mean \pm SD $)$ & $\begin{array}{l}\text { p value }(p<0.05 \text { was statisticaly } \\
\text { significant })\end{array}$ \\
\hline Mean preinduction score & $3.91 \pm 0.70$ & $3.90 \pm 0.77$ & $0.92(\mathrm{p}>0.05)$ \\
\hline Mean postinduction score & $9.10 \pm 1.49$ & $9.04 \pm 1.60$ & $0.78(\mathrm{p}>0.05)$ \\
\hline Mean change in score & $5.10 \pm 1.55$ & $5.14 \pm 1.60$ & $0.97(\mathrm{p}>0.05)$ \\
\hline
\end{tabular}

Table 3: Need for augmentation.

\begin{tabular}{|c|c|c|c|}
\hline $\begin{array}{l}\text { Mode of } \\
\text { augmentation }\end{array}$ & $\begin{array}{l}\text { Group F } \\
(n=50)\end{array}$ & $\begin{array}{l}\text { Group P } \\
(n=50)\end{array}$ & $p$ value \\
\hline None & $12(24 \%)$ & $14(28 \%)$ & $\begin{array}{l}0.62 \\
(p>0.05)\end{array}$ \\
\hline ARM & $4(8 \%)$ & $6(12 \%)$ & $\begin{array}{l}0.62 \\
(p>0.05)\end{array}$ \\
\hline Oxytocin & $19(38 \%)$ & $18(36 \%)$ & $\begin{array}{l}0.88 \\
(p>0.05)\end{array}$ \\
\hline Oxytocin+ARM & $15(30 \%)$ & $12(24 \%)$ & $\begin{array}{l}0.42 \\
(p>0.05)\end{array}$ \\
\hline
\end{tabular}

In Table 3 the need for further augmentation of labor was studied. Spontaneous labor ensued in 12 patients in Group F (24\%) compared with 14 patients in Group P (28\%). In Foley's catheter group, need for augmentation of labor was required by doing ARM $(n=4)$ oxytocin infusion $(\mathrm{n}=19)$ and both ARM + oxytocin $15(30 \%)$ patients required.

In PGE2 gel group, 6 patients required ARM, 18 patients required oxytocin and 12 patients required both ARM + oxytocin. There was no significant difference in need for augmentation in both groups.

Table 4: Mode of delivery and induction-delivery interval.

\begin{tabular}{|c|c|c|c|}
\hline Variable & $\begin{array}{l}\text { Group F } \\
(n=50)\end{array}$ & $\begin{array}{l}\text { Group P } \\
(n=50)\end{array}$ & p value \\
\hline Spontaneous & 38 & 39 & \multirow{3}{*}{$\begin{array}{l}0.88 \\
(p>0.05)\end{array}$} \\
\hline Instrumental & 2 & 3 & \\
\hline LSCS & 10 & 8 & \\
\hline $\begin{array}{l}\text { Inductiondelivery } \\
\text { interval (hours) }\end{array}$ & $16.01 \pm 5.50$ & $16.85 \pm 3.81$ & $\begin{array}{l}0.073 \\
(p>0.05)\end{array}$ \\
\hline
\end{tabular}

Table 4 shows no significant statistical difference in spontaneous vaginal delivery in both the groups. Group $\mathrm{F}$ had $76 \%(n=38)$ spontaneous deliveries whereas group $P$ had $78 \%(n=39)$ spontaneous deliveries. The need for operative intervention (LSCS) was also not significant in both the groups

Table 5 shows the incidence of perinatal asphyxia with Apgar score $\leq 7$ at 5 minutes and me conium aspiration syndromes were similar in both the groups. However the 
morbidity in both the groups was not statistically significant.

Table 5: Neonatal outcome (APGAR SCORE at 1 and 5 minutes).

\begin{tabular}{|llll|}
\hline Variable & $\begin{array}{l}\text { Group F } \\
(\mathrm{n}=50)\end{array}$ & $\begin{array}{l}\text { Group } \mathrm{P} \\
(\mathrm{n}=50)\end{array}$ & $\mathrm{p}$ value \\
\hline $\begin{array}{l}1 \text { minutes } \\
\text { APGAR }>7\end{array}$ & 38 & 38 & $\begin{array}{l}0.81 \\
(\mathrm{p}>0.05)\end{array}$ \\
\hline $\begin{array}{l}1 \text { minutes } \\
\text { APGAR }<7\end{array}$ & 7 & 6 & $\begin{array}{l}0.83 \\
(\mathrm{P}>0.05)\end{array}$ \\
\hline $\begin{array}{l}5 \text { minutes } \\
\text { APGAR }<7\end{array}$ & 5 & 6 & 0.78 \\
$\begin{array}{l}\text { (Perinatal } \\
\text { Asphyxia })\end{array}$ & & $(\mathrm{p}>0.05)$ \\
\hline \begin{tabular}{l}
$(\mathrm{p}<0.05$ was statistically significant $)$ \\
\hline
\end{tabular} & & \\
\hline
\end{tabular}

\section{DISCUSSION}

The results of the study confirm that both Foley's catheter and PGE2 gel are equally effective in pre-induction cervical ripening. The mean change in Bishops score in Foleys catheter 5.10 \pm 1.55 ( $\mathrm{p}<0.0001)$ and PGE2 gel $5.14 \pm 1.60$ ( $\mathrm{p}<0.0001)$ were highly significant. However, a comparison between the groups revealed that one method did not confer a statistically significant advantage over the other. There have been theoretic concerns regarding the introduction of infection with the use of Foley's catheter. In this study there was no infectious morbidity. Similar were the observation of Jozwiak M and Anthony $\mathrm{C}$ et al. ${ }^{11,12}$

The need for oxytocin induced augmentation of labor was $39 \%$ in Group $\mathrm{F}$ and $38 \%$ in group $\mathrm{P}$. The induction delivery interval showed no significant difference in the two groups. The mean I-D internal was $16.01 \pm 5.5 \mathrm{~h}$ in Foley's group and $16.85 \pm 3.81 \mathrm{~h}$ in PGE2 group. Similar observations were observed by Dewan et al, Pennel $\mathrm{C}$ et al. ${ }^{13,14}$ The rate of LSCS in Group F was $21 \%$ and $19 \%$ in Group $\mathrm{P}(\mathrm{p}=0.88)$. The most common indication for LSCS in Group F was fetal distress. Group F had 9 cases for FD and Group P had 11 cases of FD. The rate of LSCS in our study is agreeable. There was no association of increased rate of cesarean section with the Foley's catheter PGE2 gel use.

Fetal outcome data showed no significant difference between Group F and Group P with respect to birth wt (2.57 \pm 0.44 and $2.58 \pm 0.48$ ), MAS (4 and 4 respectively), 1 min APGAR score $<7$ (13 and 12 respectively), NICU admission rate (20 and 18 respectively). Thus the present study shows that the fetal outcome results were also comparable in both the groups. The total cost of Foley's catheter was much less than PGE2. ${ }^{15}$

In the study, the most common indication for induction of labor was pregnancy induced hypertension followed by postdated pregnancy. This is similar to the study conducted by Laddad MM et al. ${ }^{16}$

\section{CONCLUSION}

The results of study confirm that both intra-cervical Foley's catheter and PGE2 gel are effective methods for preinduction cervical ripening. This study has shown that there is no difference in efficacy between intra cervical PGE2 gel and intra cervical Foley's catheter for cervical ripening. Also, other factors like induction delivery interval maternal and neonatal outcome and need for oxytocin for further augmentation were similar in both the groups. Both methods are complementary to each other.

Drugs and material used in this study are government supply. The cost of any drugs and material in the study will not be passed on to the patient.

Funding: No funding sources

Conflict of interest: None declared

Ethical approval: The study was approved by the Institutional Ethics Committee

\section{REFERENCES}

1. Managing complication in pregnancy and childbirth: a guide for midwives and doctors. Geneva,World Health Organisation 2000. Aavailable at: http:// www. who. Int /reproductive health/ publications/ maternal_perinatal_health/ 9241545879/ en/ index. $\mathrm{Html}$ ).

2. Tofatter KF, Bowers D, Standby RN, Gall A, Killam AP. Pre-induction cervical ripening with prostaglandin E2 gel. Am J Obstet Gynecol. 1985;153:268-71.

3. Shetty A. Women's perceptions, expectations and satisfaction with induced labour - a questionnairebased study. European J Obst Gyn Reprod Biol. 2005; 123(1):56-61.

4. Onge RD, Conners GT. Preinduction cervical ripening: a comparison of intra-cervical PGE2 gel versus the Foley catheter. Am J Obstet Gynecol. 1995; 172:687-90.

5. Embrey, Mollison BG. The unfavourable cervix and induction of labour using a cervical balloon. BJOG. 1967;74:44.

6. Obed JY, Adewole IF. The unfavourable cervix: improving the Bishop score with the Foley's catheter. West Afr J Med. 1994;13(4):209-12.

7. James C, Peedicayil A, Seshardi L. Use of the Foley catheter as a cervical ripening agent prior to induction of labour. Int J Gyn Obst. 1994;47(3):22932.

8. Sherman DJ, Frenkel E, Toblin J, Arieli S, Caspi E, Bukovasky I. Ripening of the unfavourable cervix with extra-amniotic catheter balloon: clinical experience and review. Obst Gynecol Survey. 1996;51(10):621-7.

9. Arias F. Pharmacology of Oxytocin and Prostaglandins. Clinical Obst Gynecol. 2000;43(3):455-68. 
10. Sandhu SK, Arora S. Preinduction cervical ripening with endocervical PGE2 gel and a placebo control study. J Obstetgynec India. 1994;1:537-42.

11. Jozwiak M, Bloemenkamp K, Kelly A, Mol B, Irion O, Boulvain M. Mechanical methods for induction of labour. Cochrane Database Systematic Rev. 2012;3:CD001233.

12. Anthony C, Sciscione DO, Helen M. A prospective, randomized comparison of Foley catheter insertion vs. intracervical PGE2 gel for preinduction cervical ripening. Am J Obstet Gynecol. 1999;180:55-9.

13. Dewan F, Ara AM, Begum A. Foley's catheter versus prostaglandin for induction of labor. Singap J Obstet Gynaecol. 2001;32:56-63.

14. Hertelendy F, Zakar T. Prostaglandins and the myometrium and cervix. Prostaglandins Leukot Essent Fatty Acids. 2004;70:207-22.

15. Pennell C, Henderson J, O’Neill M, McCleery S, Doherty D, Dickinson J. Induction of labour in nulliparous women with an unfavourable cervix: a randomised controlled trial comparing double and single balloon catheters and PGE2 gel. BJOG. 2009; 116:1443-52.

16. Laddad MM, Kshirsagar NS, Karale AV. A prospective randomized comparative study of intra cervical Foley's catheter insertion versus PGE2 gel for pre-induction cervical ripening. Int $\mathbf{J}$ Reprod Contracept Obstetr Gynecol. 2016;2(2):217-20.

Cite this article as: Kanada AR, Jain M. A comparative study of intra-cervical foley's catheter and PGE2 gel for induction of labour at term. Int $\mathbf{J}$ Reprod Contracept Obstet Gynecol 2019;8:3689-93. 